\title{
Oral rehabilitation in a child with early childhood caries: a case report
}

\author{
Reabilitação oral em criança com cárie na \\ primeira infância: relato de caso
}

\author{
Fernanda Miori PASCON1 ID https://orcid.org/0000-0003-3337-3121 \\ Carolina STEINER-OLIVEIRA ${ }^{1}$ iD https://orcid.org/0000-0002-0680-2253 \\ Priscila Alves GIOVANI ${ }^{1}$ iD https://orcid.org/0000-0003-2280-5144 \\ Regina Maria PUPPIN-RONTANI ${ }^{1}$ iD https://orcid.org/0000-0002-1218-5159
Kamila Rosamilia KANTOVITZ1,2 iD https://orcid.org/0000-0003-2045-7924
}

\section{ABSTRACT}

The aim of the current study is to present a treatment approach in a case of severe early childhood caries (ECC). A 5-year-old girl was referred to the Pediatric Dentistry Division with multiple premature tooth loss, masticatory difficulties, prolonged breast-feeding, and low quality of life, who was diagnosed with severe ECC. A three-phased treatment plan was implemented: 1. Disease control-consisting of behavioral changes in oral hygiene habits, diet guidance, professional biofilm removal followed by fluoride application and temporary restorations; 2. Infection control - teeth extractions and pulpotomy; and 3. Functional rehabilitation - direct and semi-indirect resin restorations, a removable partial and total prostheses in the lower and upper jaws, respectively. In conclusion, the proposed multidisciplinary approach resulted in a positive impact on the patient's nutrition and growth, speech production, communication, self-image, and social functioning leading to an improved quality of life.

Indexing terms: Deciduous tooth. Dental caries. Mouth rehabilitation.

\section{RESUMO}

O objetivo do presente estudo é apresentar uma abordagem de tratamento em um caso de cárie na primeira infância (CPI). Uma menina de 5 anos foi encaminhada à área de Odontopediatria com múltiplas perdas dentárias precoces, dificuldades mastigatórias, amamentação prolongada e baixa qualidade de vida, com diagnóstico de CPI severa. Um plano de tratamento em três fases foi implementado: 1. Controle da doença - consistindo em mudanças comportamentais nos hábitos de higiene bucal, orientação alimentar, remoção profissional do biofilme seguida de aplicação de flúor e restaurações provisórias; 2. Controle de infecção - exodontias e pulpotomia; e 3. Reabilitação funcional - restaurações diretas e semi-indiretas de resina, próteses parcial e total removíveis nos maxilares inferior e superior, respectivamente. Em conclusão, a abordagem multidisciplinar proposta resultou em um impacto positivo na nutrição e crescimento do paciente, produção da fala, comunicação, autoimagem e socialização, levando a uma melhoria da qualidade de vida.

Termos de indexação: Dente decíduo. Cárie dentária. Reabilitação bucal.

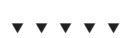

1 Universidade Estadual de Campinas, Faculdade de Odontologia de Piracicaba, Departamento de Odontologia Infantil, Área de Odontopediatria. Av. Limeira, 901, Areião, 13414-903, Piracicaba, SP, Brasil.

2 Faculdade São Leopoldo Mandic, Instituto de Pesquisas São Leopoldo Mandic, Departamento de Materiais Dentários. Rua José Rocha Junqueira, 13, Swift, 13045-755, Campinas, SP, Brasil. Correspondence to: K ROSAMILIA KANTOVITZ. E-mail: <kamilark@yahoo.com.br>.

$\boldsymbol{\nabla v}$

How to cite this article

Pascon FM, Steiner-Oliveira C, Giovani PA, Puppin-Rontani RM, Kantovitz KR. Oral rehabilitation in a child with early childhood caries: a case report. RGO, Rev Gaúch Odontol. 2021;69:e20210023. http://dx.doi.org/10.1590/1981-86372021002320190119 


\section{INTRODUCTION}

Dental caries is the most common chronic disease in childhood, consisting of a major public health problem [1] affecting 60 to $90 \%$ of the school-age children [2]. An epidemiological study has shown that in most cases the carious component accounts for more than $80 \%$ of the DMF index at the age of 5 years and more than $90 \%$ in children from 18 to 36 months, regardless of gender [3]. In Brazil, a 3-year old child already has an average of least one tooth with caries (DMFT $=1.1,95 \% \mathrm{Cl} 1.2-1.4$ ), increasing to almost 3 teeth affected teeth (DMFT $=2.8$, 95\% Cl 2.76-2.84) at older ages [3].

When this disease achieves atypical, progressive, acute, or rampant patterns at early ages, it is defined as severe Early Childhood Caries (ECC) $[1,4]$. ECC has been reported to result in pain, functional limitations and adverse effects on general health, impacting on body weight, growth and quality of life $[1,5]$. Premature deciduous tooth loss due to a number of factors, including ECC will affect speech, decrease masticatory efficiency, produce abnormal tongue habits and malocclusion, and impact on aesthetics and child's self-confidence $[6,7]$. It should also be considered that the consequences of this disease might include higher risk for the development of new carious lesions [8], increased treatment cost and time [9], and loss of school days [10].

Oral rehabilitation in patients with ECC is a complex procedure involving a multidisciplinary approach during diagnosis, treatment planning and maintenance of the oral function to maximize comfort, aesthetics and overall health [11]. Moreover, such multidisciplinary approach should emphasize prevention and health information to the parents [12]. Here, we report a complex case of severe ECC that required a multidisciplinary approach to promote rehabilitation and general health promotion in a child with dental trauma, widespread decay and high-risk-caries.

\section{CASE REPORT}

A 5-year-old girl was referred to the Pediatric Dentistry Division, Piracicaba Dental School, University of Campinas. The child's main complaints were pain during meals, aesthetics due to the loss of superior anterior teeth, and masticatory discomfort. Anamnesis reveled an annoyed and unquiet child with problems in pronouncing some words, and also with very limited relationship with other children. The child belonged to a low income and low school-level family, weighing $22 \mathrm{~kg}$ and with $117 \mathrm{~cm}$ in height. She featured extremely poor oral hygiene, absence of anterior teeth due to trauma and multiple exodontia at the age of two. Medical and dental histories exposed no contraindications to dental treatment. A three-day diet record indicated every other day frequency of ate/drank sugar containing snacks or beverages with low nutritional content between meals, revealing six daily sucrose episodes. Prolonged breast-feeding (up to 5 years old), twice at night, sucking and lip biting habits were reported; without the use of baby bottle or pacifier.

Extra-oral examination, including inspection of head, neck, and surrounding structures, was performed with no significant findings. Intra-oral examination (dental and occlusal analyses) revealed primary dentition, white spot lesions on the buccal surfaces of lower right lateral incisor and canine, severe premature tooth loss due to dental caries and trauma, and deficient resins' and glassionomer cements' restorations on the upper second molars (figure 1). Additionally, a fistula was detected at the apical region of the first mandibular molar (figure 1E). Occlusal
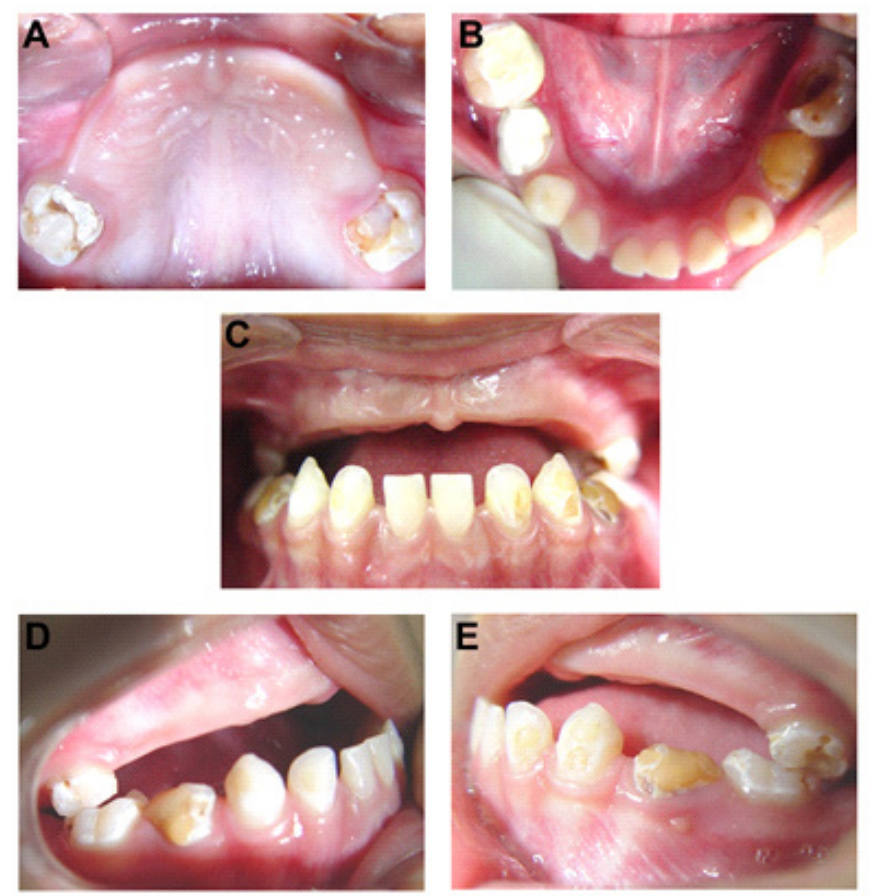

Figure 1. Pretreatment maxillary and mandibular-occlusal primary dentition views of a 5-year-old child with ECC (a). Multiple premature tooth loss (b). Presence of unsatisfactory restorations and coronary destruction (c). Frontal occlusal view (d and e) Right and left lateral occlusal views. 
analysis revealed an overall malocclusion (figure 1C-E). Radiographs were taken to assist treatment planning (figure 2). X-ray analysis showed deep caries lesions in the first and second mandibular molars on the left side with pulp involvement, internal root resorption and furcation and periapical lesions (figure 2E). Deep caries lesions were also found in the second mandibular molar with endodontic complications (figure 2C). Therefore, based on the overall data the patient was diagnosed as a case of severe ECC.

A three-phased treatment plan was implemented. Phase-I aimed at controlling disease and preventing new outbreaks. Oral hygiene was reinforced and included twice-daily use of fluoridated toothpaste, and diet adjustments. Initial procedures for improving the oral environment consisted of professional biofilm removal followed by three consecutive weekly $5 \%$ sodium fluoride varnish applications (Duraphat ${ }^{\circledR}$ - Colgate-Palmolive, São Paulo, SP, Brazil). In addition, conventional glass-ionomer cement (Ketac Molar Easymix ${ }^{\circledR}$ - 3M/ESPE, Maplewood, Minnesota, USA) restorations were used (figure 1).

Phase-II focused on infection control and included the surgical removal of the upper second molars, as well as the first and second mandibular left molars. Patient recovery occurred without reporting any abnormal signs or symptoms. Sutures were removed 7 days after teeth extractions and favorable healing process was observed. Pulpotomy was performed in the primary mandibular second molar (right side) using a conventional technique [14]. Briefly, after controlling bleeding with sterile dry cotton pellets, diluted formocresol (1/5) was placed on the radicular pulp stumps for 5 minutes followed by the use of Intermediate Restorative Material (DENTSPLY, Catanduva, São Paulo, Brazil) to fill the pulp space in the tooth crown, and glass-ionomer cement restoration (Ketac Molar Easymix $^{\circledR}$ - 3M/ESPE, Maplewood, Minnesota, USA). Resin composite restorations were placed in the left lower lateral incisor and canine, and right lower first and second molars (Z-250, Shade A1, 3M/ESPE Dental Products, São José, SC, Brazil).

Phase III included functional rehabilitation with a removable total and partial prostheses in the upper and lower jaws, respectively (figure 3). In brief, impressions of the lower and upper jaws were obtained using conventional tray and alginate. Next, an individual tray with acrylic resin was prepared and the impressions were performed with a condensation silicone impression material. Centric positions of the jaws were obtained using occlusal waxes, and the working models were mounted on an articulator. Prostheses were processed of acrylic resin heat-cured. Recommendations on speech, eating and daily maintenance of the prosthesis was given to the parents. After one week, the patient returned for fine adjustments and to evaluate the oral condition and prostheses adaptation. Three adjustment appointments were scheduled to diminish prostheses' discomfort and

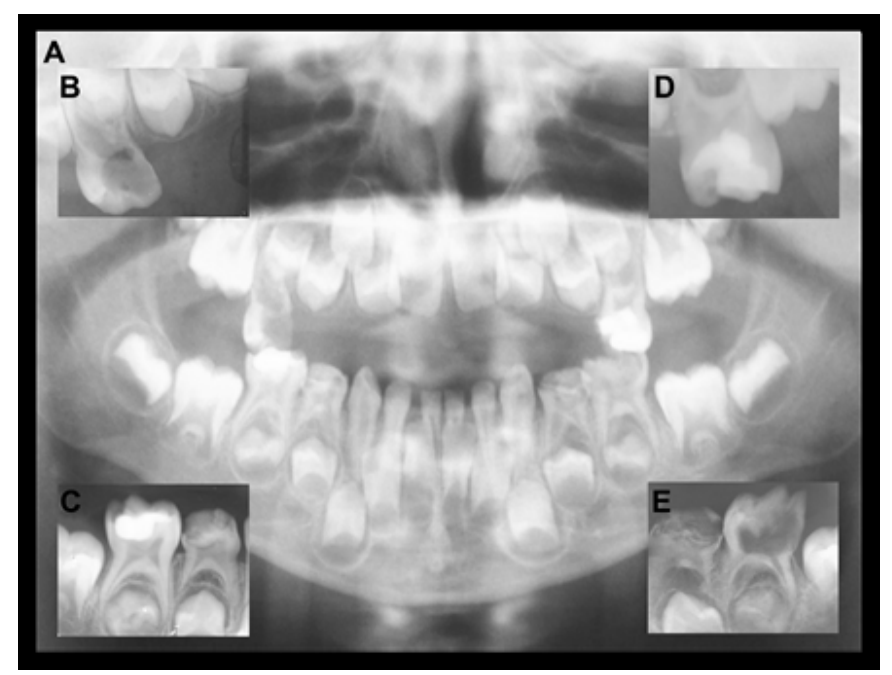

Figure 2. Radiographic examinations (a). Panoramic radiographic revealed no abnormalities ( $b$ and $d$ ). Periapical radiographic of primary maxillary right and left second molar, respectively (c and e). Periapical radiographic of primary mandibular right and left first and second molars, respectively.
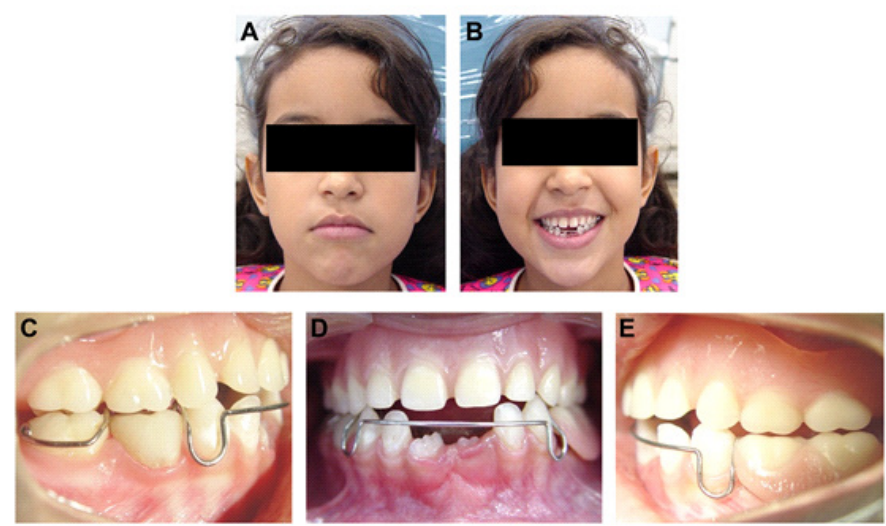

Figure 3. Final appearance of functional rehabilitation: maxillary total and mandibular removable partial dental prosthesis. Right-, frontaland and left- view after treatment and adaptation of dental prosthesis. 
the patient was referred to a speech specialist to address phonetic problems. The patient was seen weekly during the first month and monthly up to the 12-month appointment. Guidelines on oral hygiene were carried out, followed by recommendations of prostheses use, so the patient should not remove them during chewing. Assessed clinical parameters included: biofilm index, oral hygiene practices, dietary habits, health care attitude, occlusal evaluation, physical status, mental and social factors, systemic disease and medication. The mother reported improvement in self-esteem, social behavior, nutrition, phonation and both, family and patient were very satisfied with the treatment.

\section{DISCUSSION}

The present case report, with a 12-month follow-up period, presents a multidisciplinary approach in a child with severe ECC associated with dental trauma $(\mathrm{dmf}-\mathrm{t}=18)$. This case highlights a multifactorial etiology for dental caries: diet associate with prolonged breastfeed, inadequate oral hygiene habits, low mother's education, low socioeconomic status of the family, and high sugar ingestion between meals $[1,11]$. In addition, it highlights the importance of an integral and articulated vision between related areas in dentistry allowing for the reestablishment and maintenance of favorable oral and general health conditions for proper development of the patient $[9,13,14]$. Consequences of untreated ECC include a higher risk of new carious lesions in both the primary and permanent dentitions, hospitalizations and emergency room visits, increased treatment costs, risk for delayed physical growth and development, loss of school days and increased days with restricted activity, diminished ability to learn and diminished oral health-related quality of life $[10,14,15]$. In addition, it has been reported that appropriate dental treatment may also have a positive impact on psychological and social aspects related to the child's life $[7,8,14]$. LorençoNeto et al. [16] have demonstrated that a comprehensive approach for a patient presenting ECC will impact beyond the oral environment, restoring psychological aspects and promoting prevention. As far as caries risk, we found that the present case features conditions previously reported to be associated with increased risk for ECC, including a low socioeconomic status, lower school-level, long periods of breastfeeding (24 months or more) and a fairly low nutritional health compared to children without carious lesions [15,17-20].
In the current case, treatment was proposed as a 3-phased approach. Phase-I aimed at improving oral hygiene and patient's diet, and included topical fluoride application, oral hygiene instructions, dietary habits, use of fluoridated toothpaste and a periodic follow-up. Overall, a significant improvement was achieved at the end of Phase I with regards to biofilm control and nutritional condition. A previous 3-year follow-up study [21] have demonstrated a $43 \%$ reduction in the development of new carious lesions in children who had associated daily tooth brushing with a fluoridated toothpaste and who received oral health education in comparison with children that followed a normal kindergarten routine without any form of intervention. Because children diagnosed with ECC are at greater risk for carious lesions in the permanent dentition [22], in the present case, Phase I will play a key role preventing caries from impacting on permanent dentition.

Phase-ll focused on infection control and included dental extractions, endodontic procedures, and dental fillings. For deciduous teeth submitted to pulpotomy, instead of using direct crowning, indirect crowns were used with the advantage of reestablishing a physiological anatomy and relationship with the soft tissues, minimizing variables associated with direct placement techniques, and creating a more homogeneous, durable and aesthetic outcome $[23,24]$. In order to successfully proceed with dental restorations, short duration sessions were preferred, demanding a larger number of appointments, with great involvement and commitment of the parents. Compared with treatment under general anesthesia in a single session, where the parents are not engaged with the treatment, short duration sessions have the advantage to engage the parents and not only allow them to see the clinical procedures performed [25], but also play a key role preventing failure at a long term basis. The American Academy of Pediatric Dentistry recommends that infant oral health begins with prenatal oral health counseling for parents; a postnatal initial oral evaluation should be performed within six months of the eruption of the first primary tooth in an infant but by no later than 12 months of age [26]. However, the utilization of care can also be influenced by differences in culture and language. Endodontically affected teeth have been linked to a child growth rate as chronic endodontic inflammation may affect erythropoiesis leading to a anemic condition through systemic inflammatory markers release, including for example interleukin-1 (IL-1) [27]. In the present case, 
pulpotomy allowed for the complete control of endodontic pathologies leading to an effective pain control and reestablishment health status in surrounding soft tissues.

Primary tooth loss, due to dental caries or trauma, are usually very impacting and might cause a series of oral consequences including disorders of mastication and speech, loss of space, and psychological events that may the interaction with other children, as also demonstrated here. In the current case, Phase III treatment aimed at fully rehabilitating the functional and aesthetical aspects resulting from the early primary tooth loss. After prosthetic rehabilitation, the patient expressed pleasure with her appearance and seemed more receptive to greater social integration becoming more cheerful and communicative. These observations are in line with a previous report on the impact of oral rehabilitation on an increased patient self-esteem $[5,8,16]$. Total and partial removable dental prosthesis were used to prevent malocclusion and to recover oral function. Overall, parents reported that the treatment positively impacted the patient's self-esteem due to improved aesthetic appearance and that the restoration of the anatomical shapes of the teeth allowed the child to chew better. At the one-year follow-up, intraoral examination showed a satisfactory oral health, with low levels of biofilm and normal periodontal characteristics. Removable partial dentures were stable and the child was satisfied with her state of health.

\section{CONCLUSION}

Inconclusion, a comprehensive and multidisciplinary approach including preventive, psychological, and curative measures to deal with a child diagnosed with severe ECC, was found to fully restore the child's oral function and aesthetics allowing for a normal psychosocial development. In addition, systematic visits for follow-up play an essential role in keeping the child and family motivated with biofilm/ diet control positively impacting on the longevity of the outcome.

\section{Collaborators}

FM PASCON, C STEINER-OLIVEIRA were responsible for conceptualization, methodology, resources, writing-review \& editing. PA GIOVANI was responsible for conceptualization, writing-original draft, writing-review \& editing. RM PUPPIN-
RONTANI was responsible for conceptualization, methodology, resources, supervision, writing-review \& editing. KR KANTOVITZ was responsible for conceptualization, methodology, resources, supervision, writing-original draft, writing-review \& editing.

\section{Acknowledgments}

The authors thank the Department of Pediatric Dentistry, State University of Campinas, Piracicaba Dental School. In special, we thank Dr. Cecília Gatti Guirado (in memoriam) for her cooperation and assistance managing this case.

\section{REFERENCES}

1. American Academy of Pediatric Dentistry. Policy on Early Childhood Caries (ECC): classifications, consequences, and preventive strategies. Pediatr Dent. 2017;39(6):59-61.

2. Petersen PE, Bourgeois D, Ogawa H, Estupinan-Day S, Ndiaye $C$. The global burden of oral diseases and risks to oral health. Bull World Health Organ. 2005;83(9):661-669.

3. Brasil. Ministério da Saúde. Projeto SB Brasil: condições de saúde bucal da população brasileira 2002-2003 [citado 2020 Ago 10]. Disponível em: <http://bvsms.saude.gov.br/bvs/ publicacoes/projeto_sb2004.pdf>.

4. Drury TF, Horowitz AM, Ismail Al, Maertens MP, Rozier RG, Selwitz RH. Diagnosing and reporting early childhood caries for research purposes. A report of a workshop sponsored by the National Institute of Dental and Craniofacial Research, the Health Resources and Services Administration, and the Health Care Financing Administration. J Public Health Dent. 1999;59(3):192-197. https://doi. org/10.1111/j.1752-7325.1999.tb03268.x

5. Ramos-Jorge J, Pordeus IA, Ramos-Jorge ML, Marques LS, Paiva SM. Impact of untreated dental caries on quality of life of preschool children: different stages and activity. Community Dent Oral Epidemiol. 2014;42(4):311-322. https://doi.org/10.1111/cdoe.12086

6. Zou J, Meng M, Law CS, Rao Y, Zhou X. Common dental diseases in children and malocclusion. Int J Oral Sci. 2018;10(1):7. https://doi.org/10.1038/s41368-018-0012-3

7. Golai S, Nimbeni B, Patil SD, Baali P, Kumar H. Impact of untreated traumatic injuries to anterior teeth on the oral health related quality of life as assessed by video based smiling patterns in children. J Clin Diagn Res. 2015;9(6):ZC16-ZC19. https://doi.org/10.7860/JCDR/2015/13169.6039

8. Martins MT, Sardenberg F, Bendo CB, Abreu MH, Vale MP, Paiva SM, et al. Dental caries remains as the main oral condition with the greatest impact on children's quality of life. PLoS One. 2017;12(10):e0185365. https://doi.org/10.1371/ journal.pone.0185365

9. Duangthip D, Jiang M, Chu CH, Lo EC. Restorative approaches to treat dentin caries in preschool children: systematic review. Eur J Paediatr Dent. 2016;17(2):113-121.

10. Anil S, Anand PS. Early childhood caries: prevalence, risk factors, and prevention. Front Pediatr. 2017;5:157. https:// doi.org/10.3389/fped.2017.00157 
11. Rane JV, Winnier J, Bhatia R. Comparative assessment of oral health related quality of life of children before and after full mouth rehabilitation under general anaesthesia and local anaesthesia. J Clin Diagn Res. 2017;11(1):ZC23-ZC26. https:// doi.org/10.7860/JCDR/2017/23699.9163

12. Dabawala S, Suprabha BS, Shenoy R, Rao A, Shah N. Parenting style and oral health practices in early childhood caries: a case-control study. Int J Paediatr Dent. 2017;27(2):135-144. https://doi.org/10.1111/ipd.12235

13. Rölling I, Thylstrup A. A 3-year clinical follow-up study of pulpotomized primary molars treated with the formocresol technique. Scand J Dent Res. 1975;83(2):47-53. https://doi. org/10.1111/j.1600-0722.1975.tb00419.x

14. Sachdev J, Bansal K, Chopra R. Effect of comprehensive dental rehabilitation on growth parameters in pediatric patients with severe early childhood caries. Int J Clin Pediatr Dent 2016;9(1):15-20. https://doi.org/10.5005/jpjournals-10005-1326

15. Moynihan P, Tanner LM, Holmes RD, Hillier-Brown F, Mashayekhi A, Kelly SAM, et al. Systematic review of evidence pertaining to factors that modify risk of early childhood caries. JDR Clin Trans Res. 2019;4(3):202-16. https://doi. org/10.1177/2380084418824262

16. Lourenço-Neto N, Cardoso CAB, Camargo RC, da Silva SMB. Oral rehabilitation in pediatric dentistry: a clinical case report. RGO, Rev Gaúch Odontol. 2016;64(1):87-91. https://doi. org/10.1590/1981-863720160001000131064

17. Matijasevich A, Barros AJD. Impact of prolonged breastfeeding on dental caries: a population-based birth cohort study. pediatrics. 2017;140(1):pii: e20162943. https:// doi.org/10.1542/peds.2016-2943

18. Peres KG, Chaffee BW, Feldens CA, Flores-Mir C, Moynihan P, Rugg-Gunn A. Breastfeeding and Oral Health: Evidence and Methodological Challenges. J Dent Res. 2018;97(3):251-258. https://doi.org/10.1177/0022034517738925

19. Chhonkar A, Gupta A, Arya V. Comparison of Vitamin D level of children with severe early childhood caries and children with no caries. Int J Clin Pediatr Dent. 2018;11(3):199-204. https://doi.org/10.5005/jp-journals-10005-1511
20. Oliveira LB, Sheiham A, Bonecker M. Exploring the association of dental caries with social factors and nutritional status in Brazilian preschool children. Eur J Oral Sci. 2008;116(1):37-43. https://doi.org/10.1111/j.1600-0722.2007.00507.x

21. Schwarz E, Lo EC, Wong MC. Prevention of early childhood caries--results of a fluoride toothpaste demonstration trial on Chinese preschool children after three years. J Public Health Dent. 1998;58(1):12-18. https://doi. org/10.1111/j.1752-7325.1998.tb02985.x

22. Llena C, Calabuig E. Risk factors associated with new caries lesions in permanent first molars in children: a 5-year historical cohort follow-up study. Clin Oral Investig. 2018;22(3):15791586. https://doi.org/10.1007/s00784-017-2253-5

23. Rabêlo RT, Caldo-Teixeira AS, Puppin-Rontani RM. An alternative aesthetic restoration for extensive coronal destruction in primary molars: indirect restorative technique with composite resin. J Clin Pediatr Dent. 2005;29(4):277-281. https://doi.org/10.17796/jcpd.29.4.03j1681317015260

24. Motisuki C, Santos-Pinto L, Giro EM. Restoration of severely decayed primary incisors using indirect composite resin restoration technique. Int J Pediatric Dent. 2005;15(4):282-286. https://doi.org/10.1111/j.1365-263X.2005.00645.x

25. Jankauskiene B, Virtanen J, Kubilius R, Narbutaite J. Oral health-related quality of life after dental general anesthesia treatment among children: a follow-up study. BMC Oral Health. 2014;14:81. 25. https://doi.org/10.1186/1472-6831$14-81$

26. American Academy of Pediatric Dentistry. Oral health policies American Academy of Pediatric Dentistry. Pediatr Dent 2003;25(7 Suppl):11-49.

27. Means RT Jr, Krantz SB. Progress in understanding the pathogenesis of the anemia of chronic disease. Blood 1992;80(7):1639-1647.
Received on: $29 / 7 / 2019$

Final version resubmitted on: 17/2/2020

Approved on: 27/2/2020 